\title{
CONCEPTUAL MODEL OF FORMATION OF ECOLOGICAL COMPETENCY OF FUTURE TEACHERS OF NATURAL SCIENCES
}

\author{
Inna Siaska \\ Ph.D., Associate Professor, Rivne State University of Humanities, Ukraine \\ e-mail: syaskainna@gmail.com,orcid.org/0000-0002-6096-1335
}

\section{Summary}

The aim of this paper is to substantiate the approaches to modeling the pedagogical system of formation of ecological competency of future teachers of natural sciences in the process of professional training in higher education. The essence of the terminological apparatus of the researched problem is analyzed and the pedagogical concept of research is offered. The content and structure of the conceptual model of formation of ecological competency of future teachers of natural sciences are determined. The structure of the model includes the following interconnected component blocks: conceptual-methodological, theoretical-contents, organizational-procedural, diagnostic-evaluation. The conceptual and methodological block contains methodological principles and approaches to the formation of ecological competency of future teachers of natural sciences, pedagogical patterns and a system of principles of organization of the educational process aimed at achieving this goal. The theoretical-contents block of the model represents the components of the content of the educational process of ecological training of future teachers of natural sciences, which have a psychological and pedagogical influence on the formation of structural components of ecological competency of the individual. The organizational-procedural block includes components that directly reflect the interconnected forms, means and technologies of realization of the content of the educational process aimed at the formation of ecological competency of future teachers of natural sciences. Diagnostic and evaluation unit is represented by diagnostic tools and methods of its application, as well as reflects the criteria, indicators and levels by which the assessment of the state of formation of ecological competency of future teachers of natural sciences.

Keywords: ecological competency, future teacher of natural sciences, pedagogical system, modeling, conceptual model.

\section{DOI https://doi.org/10.23856/4109}

\section{Introduction}

The approach to the process of formation of ecological competency of future teachers of natural sciences should be carried out comprehensively and systematically, as the category «competency» covers both knowledge and practical areas and personal qualities that determine its environmentally sound behavior and activities in everyday life and in the profession. Therefore, to implement this task it is necessary to develop a conceptual model that would summarize all pedagogical patterns and methodological approaches to the formation of systemic relationships between the educational environment, components of the educational process and its subjects and reflect the nature, content and features of ecological competency of future teachers natural sciences in the process of their professional training in a higher education institution. Substantiation of the content of the conceptual model is determined by the concept of the study, as well as the results of the ascertaining stage of the pedagogical experiment 
and the identified shortcomings and problems in the content of professional training of future teachers of natural sciences in the context of formation of their ecological competency.

\section{The essentiality content of the concepts of the investigated problem}

Before substantiating the conceptual model of formation of ecological competency of future teachers of natural sciences, it is necessary to reveal the essential content of its terminological and conceptual apparatus in the context of our study: pedagogical concept, pedagogical system, pedagogical model, structure, model component.

Under the concept of pedagogical concept S. Goncharenko understands a system of views, ideas or principles on a particular pedagogical phenomenon or process and their interpretation as a leading idea of pedagogical theory (Goncharenko, 1997: 177). E. Yakovlev, N. Yakovleva, taking into account the specifics of pedagogical research, give the following definition of pedagogical concept: «...complex, purposeful, dynamic system of fundamental knowledge about the pedagogical phenomenon, which fully and comprehensively reveals its essence, content, features, as well as the technology of operating with it in modern education» (Yakovlev, Yakovleva, 2006: 10).

Thus, the interpretation of the concept of "pedagogical concept" primarily determines the content and strategy of a particular pedagogical activity, the system of views and approaches to understanding a particular pedagogical phenomenon, phenomenon or process, pedagogical patterns of the educational process aimed at achieving a specific goal.

In this context, the pedagogical concept of our study contains the following components: the purpose of the concept, the provisions and patterns on which it is based, the main approaches and system of principles of organization of the educational process aimed at achieving goals. The concept of the study is based on:

- fundamental philosophical and cultural provisions on the dialectical knowledge of phenomena and processes of interdependence and interaction of nature and man, which substantiate the ideas of coevolution of sustainable development of nature and society and the need to harmonize interactions in the system «nature - man - society»;

- psychological and pedagogical principles of updating the educational process in institutions of higher pedagogical education, the main objectives of which are to intensify the process of professional training through the introduction of a competency-based approach;

- improving the quality of training of future teachers of natural sciences, which is provided by successive stages of the process of acquiring knowledge, skills and abilities (feeling, perception, comprehension, understanding, generalization, practical consolidation, experience) and is the integration of knowledge, values and motivational components of personality as the basis of its behavior and activities in the environment.

In particular, the concept of competency ecological training of future teachers of natural sciences aims at theoretical and methodological substantiation of the content, forms, means and technologies of formation of ecological competency of future teachers of natural sciences in the educational process and pedagogical system of the specified phenomenon.

Thus, the philosophical and methodological foundations on which the pedagogical concept of competency ecological training of future teachers of natural sciences is based are ontological, epistemological, axiological and praxeological methodological provisions that most fully reveal the multifaceted essence of the genesis of ecological competency of the individual.

Based on the analysis of theoretical sources we have proved that the problem of formation of ecological competency of students majoring in Secondary Education (Biology and Human 
Health, Physics, Chemistry, Natural Sciences) in the process of professional training is solved by applying a number of methodological approaches in the organization of the educational process, namelysynergetic combination of competency approach with systemic, personality-oriented, activity, technological, contextual, reflective and coevolutionary-noosphere methodological approaches (Siaska, 2020).

The implementation of these approaches is based on the general pedagogical patterns of the educational process relating to the training of future teachers, and partial pedagogical patterns , which are subject to and ensure the effectiveness of the formation of their ecological competency. In particular, the latter, according to our justification, include: 1) socio-pedagogical conditionality of the content of environmental education and upbringing in higher education institutions in accordance with the public demand for sustainable development of nature and society; 2) functional dependence of the content on the purpose and tasks of competency ecological education and education of students, caused by educational standards; 3 ) the unity of the structural components of the educational process (content, forms, methods, tools), aimed at forming the ecological competency of future teachers of natural sciences; 4) interdisciplinary interaction of humanitarian and natural science education in the formation of ecological value orientations, ecological consciousness, culture and worldview of student youth; 5) stages and sequence of the relationship of theoretical and practical ecological training of future teachers with the gradual acquisition of experience in their application in professional activities; 6) the relationship between the development of personal qualities of students (interests, needs, motives, beliefs, subjective attitude to nature) with the formation of ecological competency of future teachers (Siaska, 2020: 218-219).

The list of principles for constructing the content of the educational process of professional training of future teachers of natural sciences in the context of forming their ecologicalcompetency includes: fundamental pedagogical principles of cultural conformity and nature conformity in combination with didactic principles of teaching (purposefulness of training; system and sequence; scientificity; accessibility; continuity; connection of learning with life and practice; professional orientation) and upbringing (focus on the relationship of learning, education and personal development; activity and creative independence; unity of consciousness and behavior; motivation; individual and differentiated approach). They are in logical unity with certain specific principles of the competency approach (humanization and democratization of the educational process; continuity of professional pedagogical education; variability; interdisciplinarity; reliance on the leading achievements of science, technology and information technology and integration of science and practice; socio-value orientation of activities teacher) and ecological education and upbringing (unity of content and objectives of environmental education and upbringing; systemicity and continuity; transdisciplinarity of environmental knowledge; the relationship of local, regional and global approaches in the educational process; integrity and integrativity; focus on the development of emotional and motivational activity sphere of personality; ecological profiling of teacher training), will allow to construct the content of the educational process aimed at the formation of ecological competency of future teachers in the field of natural education.

Thus, the concept of our study provides a theoretical and methodological basis for defining and justifying the content, forms, tools and technologies of the educational process and establishing systemic links and relationships between them with the ultimate goal of forming environmental competency of future teachers.

The term «system» comes from the word «systema», which translated from Greek means a certain integrity, which forms a hierarchical structure by a combination of components, elements with connections or relationships between them (Bespalko, 1977). 
In pedagogy, the concept of «system» is seen as a holistic structure of a pedagogical object or process formed by a set of elements with hierarchical links between them, which arise as a functional association around the purpose of educational activities and its management (Babansky, 1997; Bespalko, 1977; Goncharenko, 1997). The main feature of pedagogical systems is their integrity in interaction with the socio-cultural environment. In this context, T.A. Ilyina notes the interconnectedness and interdependence of all components of the system, «...when changes in one part lead to changes in other parts and in the system as a whole» (Ilyina, 1972: 17). At the same time, according to V. Afanasyev, the interaction of the components of the system determines the presence of integral qualities that are not characteristic of its individual elements (Afanasyev, 1980: 10).

Thus, we can conclude that the pedagogical system, the constituent elements of which and the relationships between them form a single structure, works to achieve a specific educational goal, which in turn determines its essential characteristics and composition. In turn, the systematic vision of the educational process, as noted by O. Voitovych, «... allows to identify its components, analyze all the diversity of connections and relationships between them and on this basis to guide the pedagogical process in the desired direction» (Voitovych, 2018: 135) .

Summarizing the positions of scientists, we concluded that the pedagogical system is characterized by the following features: the integrity and unity of structural elements, the presence of psychological and pedagogical links and relationships between elements and environment that determine the integrated qualities of the system, hierarchical structure and management. goals of educational activities (Afanasyev, 1980; Babansky, 1997; Bespalko, 1977; Goncharenko, 1997). In turn, the design of the pedagogical system involves the creation of a model of the educational process, which will be characterized by the above features.

\section{Modeling of the pedagogical system of formation of ecological competency of future teachers of natural sciences}

In the explanatory dictionary of the Ukrainian language the concept of «model» (from the Latin modulus - measure, sample, sample) is explained as an artificially created analogue, which in structure, structure close to the real object, mimics its properties and action, used to obtain new knowledge about the object. Here, another definition is proposed, according to which the model is interpreted as «... a conditional image of any object, process or phenomenon used as its «representative»» (Large Explanatory Dictionary of the Modern Ukrainian Language, 2001: 683).

Regarding the interpretation of the essence of the pedagogical model, it is necessary to take into account such features as uncertainty of the results of its design in the long run, because the object of modeling is a pedagogical phenomenon (process), which undergoes constant changes due to personal development of its subjects. In this regard, E. Lodatko notes that the widespread use of models in pedagogical research is due to the need to formalize (schematize) the studied pedagogical object in order to track its qualitative features, defining characteristics, principles of internal organization to be studied, evaluated and managed (Lodatko, 2011: 339-340). Thus, this approach makes it possible to identify the most important components of the object of study, to determine the links and interdependencies between them, to establish patterns of their functioning, development trends and predict the consequences of various factors and innovations. A similar opinion was expressed by V. Mikheev, justifying the feasibility of «... study of pedagogical phenomena and processes on a special object - a model that is an intermediate link between the subject - teacher, researcher and subject of study, ie certain properties and relationships between elements of educational process» (Mikheev, 2006: 5). 
Thus, taking into account these positions of scientists, we consider the pedagogical model as a projection of the pedagogical system, which reproduces its structure, characteristics and the set of relationships between its components, due to the goal and objectives of educational activities.

Regarding the typology of models, different criteria for their division are used in pedagogical research. In particular, A. Panfilova's interpretation (Panfilova, 2006: 25), where it is stated: «A model is a reproduction or description of a certain phenomenon or process, can be static, ie reflect the structure of the original, or dynamic, ie reflect the behavior, functioning of the original», - gives grounds for the conclusion that the peculiarities of the reflection of the pedagogical object, phenomenon or process of the model are structural, functional or mixed (structural-functional). At the same time, in the researches devoted to the problems of professional training of the future teacher, according to M. Jakubowski, insulated pedagogical models dominate in accordance with the degree of coverage of educational activities (Jakubowski, 2003: 12). Whereas in higher pedagogical education in accordance with modern socio-educational needs there is a need to create comprehensive models of professional teacher training, based on trends in socio-economic development of post-industrial society, which requires training of highly qualified teachers able to competently and comprehensively implement professional tasks, master and apply innovative technologies in teaching and educating the younger generation. To this end, in our opinion, it is advisable to construct a conceptual model that not only most fully reflects the structure of the modeled pedagogical system, but also takes into account methodological principles and approaches to the study of the object, features of its functioning and areas of improvement in the educational environment as conditions for achieving a specific goal of modeling.

A similar vision of modeling the pedagogical system is offered by N. Nychkalo, who points to the need to take into account in its hierarchical structure the unity of content, forms, methods and means of educational process aimed at achieving its goal and criteria of functional interaction with society (Nychkalo, 2004: 285).

Thus, in the context of our study, we consider the conceptual model of formation of ecological competency of future teachers of natural sciences in the process of professional training as a pedagogical system with a characteristic internal structural integrity due to its target direction, provided by unity of integrative connections educational process and educational environment, which at the same time is an element of another higher order pedagogical system, aimed at training teachers with certain conceptual principles of its activities.

The process of pedagogical modeling consists of a number of stages: heuristic search of the project model, theoretical substantiation of the content and structural-functional connections of the model, its implementation and testing in educational activities, analysis of the results of practical application in educational activities and forecasting its further development. It should be noted that at each stage of model construction a certain level of abstraction of the reproduced pedagogical object or phenomenon is used. Therefore, we agree with the opinion of scientists who consider modeling as a process of creative analytical-synthetic activity, the end result of which is the creation of a certain constructive reflection of the object under study, its target orientation, structural and functional characteristics and properties. Thus, the main purpose of designing a model (pedagogical system) is to improve the educational process and the corresponding correction of all its components, aimed at developing mechanisms and ways to achieve a specific educational goal.

Accordingly, the use of modeling in pedagogical research has a clear functional purpose, which, according to V. Mikheev, consists of several aspects: epistemological (the model serves as an intermediate object of the means of cognition of a particular pedagogical phenomenon or process); 
general methodological (serves as a means of assessing structural relationships and relationships between components within the system and with higher-order systems); psychological (allows to identify psychological and pedagogical patterns in the process of pedagogical and educational activities) (Mikheev, 2006: 8). Taking into account these aspects in the modeling process allows to determine the optimal mechanisms for managing the system under study, interpretation of the effects of socio-pedagogical factors on the development of the system.

\section{The structure of the conceptual model of the formation of ecological competency}

Thus, in the process of building a conceptual model of formation of ecological competency of future teachers of natural sciences, we designed a structure that will consist of the following interconnected component blocks: conceptual-methodological, theoreticalcontents, organizational-procedural, diagnostic-evaluation. The conceptual and methodological block corresponds to the concept of our study and contains methodological principles and approaches to the formation of environmental competency of future teachers of natural sciences, pedagogical patterns and a system of principles of organization of the educational process aimed at achieving this goal.

Since in the course of our research the pedagogical expediency of introduction of competency-oriented education and system of ecological education and upbringing based on the idea of coevolution of sustainable development of nature and society into the practice of higher pedagogical school is substantiated, the content of educational process is focused on increasing ecological competency of future teachers. Thus, the theoretical-contents block of the model represents the components of the content of the educational process of ecological training of future teachers of natural sciences, which exert psychological and pedagogical influence on the formation of structural components of ecological competency of personality: informationcognitive, value-motivational, professional-activity, reflective-behavioral are formed in the conditions of educational environment of the institution of higher pedagogical education. Hence, the content of the educational process is represented by a set of interrelated aspects that resonate with the structure of environmental competency of the individual: knowledge and information - mastering the system of environmental knowledge and skills of analysis and synthesis of environmental information; practical-experienced - the acquisition of practical skills and abilities to use environmental knowledge in practice and gain experience in their application in everyday life and professional activities; personal - the formation of a system of value ecological orientations, beliefs and motivations for environmentally sound behavior and activities. Thus, the content of the educational process of ecological training of future teachers is an integrated system of ecological knowledge, skills and abilities based on ecological values and personal beliefs, which together motivate future teachers to their practical implementation in further professional activities on the basis of environmental feasibility.

In educational-professional programs (EPP) of training of future teachers of natural sciences the specified maintenance is represented by the list of educational content of educational disciplines of an ecological direction which are conditionally divided by us into three groups: theoretical and applied ecology, methodology of ecological education and upbringing (included in a cycle of professional training) and disciplines of the general cycle of training, which determine the theoretical foundations of the formation of ecological culture and worldview of students. The knowledge, skills and abilities acquired as a result of their study and experience of their application in professional activity students can realize during their industrial (pedagogical) practice and writing of course and qualification works. The analysis of EPP in 
the specialty of Secondary Education (Biology and Human Health, Natural Sciences, Physics, Chemistry) allowed us to conclude that in their content the disciplines of theoretical and applied ecology are presented quite widely, in different variations, while the subjects of the second and third groups practically absent. Therefore, the content of the educational process of ecological training of future teachers of natural sciences we have developed and included the disciplines «Concept of sustainable development» of the cycle of general training and «Theory and practice of ecological education and upbringing» - professional. The latter discipline is necessary to provide methodological training for future teachers in the implementation of ecological education and upbringing of students. In turn, the «Concept of sustainable development» in its content substantiates the principles of ecologically balanced nature management, which provide for the coordination of ecological, economic and social factors of development of society and reveals the role of education in overcoming the environmental crisis and society.

The organizational-proceduralblock includes components that directly reflect the interrelated forms, means and technologies of realization of the content of the educational process aimed at the formation of ecological competency of future teachers of natural sciences. In particular, the forms of organization of the educational process are flexible and diverse. In addition to traditional forms of education: classroom and extracurricular activities and independent work of students, along with full-time (day, evening) and part-time forms of education used distance, normative (cross), double graduation opportunities and academic mobility.

But the peculiarity of competency education is the emphasis on practical training of students, which involves the acquisition of knowledge, skills and abilities in the process of teaching and research activities during laboratory workshops and training and production practices, realization of environmental research.

We propose to strengthen the practical implementation of the study of these disciplines by intensifying the participation of future teachers of natural sciences in the work of environmental NGOs, environmental movements, volunteer and educational activities with the involvement of student government. Thus, means of implementation of ecological education and upbringing of student youth are the ecological component of the content of the disciplines of the general cycle of training, ecological disciplines (subjects directly designed to form ecological knowledge of students and methods of ecological education and education in general secondary education institutions); ecological research activities; environmental, volunteer and educational work of student government.

In our opinion, it is expedient to implement the mentioned content, forms and means of ecological training of future teachers of natural sciences with the use of problem-based learning technologies, interactive, game, information-communication and project technologies.

In turn, the diagnostic-evaluation block is represented by diagnostic tools and methods of its application, as well as reflects the criteria, indicators and levels by which the assessment of the state of ecological competency of future teachers of natural sciences. Thus, the assessment of the state of formation of ecological competency of students was carried out with the involvement of proven methods on cognitive, axiological, practical-procedural, normative-ideological criteria with appropriate diagnostic indicators. Three levels of formation of ecological competency of future teachers of natural sciences are defined and substantiated: low - unconscious (involuntary) incompetency, average - conscious (arbitrary) incompetency, high - conscious (arbitrary) competency.

In addition to these component blocks of the model, it includes two important structural elements that determine the target effectiveness of the conceptual model and are key in its structure: input - the purpose of its creation and final - the effectiveness of its implementation in 
the educational process. Thus, the purpose of the conceptual model is the systematic formation of ecological competency in the process of training future teachers of natural sciences, respectively, the result of effective implementation of the model is to increase the level of formation of this competency of students of natural sciences. All the above structural blocks are connected with two key elements and reflect each other and reflect the stages, logical sequence and interaction in the system of environmental training of future teachers, implemented in the relevant educational environment of higher education and with certain pedagogical conditions, which ensure the efficiency and stability of functioning of the conceptual model.

\section{Conclusions}

Thus, the proposed conceptual model presents the pedagogical system of formation of ecological competency of future teachers of natural sciences as a holistic reflection of the educational process from goal setting to the final result, formed by the interaction of component blocks: conceptual-methodological, theoretical-content, organizational-procedural and diagnostic-evaluation. The structure of the model allows to monitor the implementation of the concept of ecological training of students in the content of the component blocks of the model, to track direct and feedback links between them, reflecting the conditionality of the forms of organization of the educational process, technologies and means of formation of ecological competency and diagnostics of the state of formation. The introduction of a conceptual model in the process of professional training of future teachers of natural sciences requires taking into account the peculiarities of the educational environment and pedagogical conditions of the educational process, which is the next stage of our study.

\section{References}

Afanasev, V.G. (1980). Sistemnost i obschestvo [Systematic and society]. Moskva: Politizdat [in Russian].

Babanskiy, Yu.K. (1997). Optimizatsiya protsessa obucheniya: obschedidakticheskiy aspect [Optimization of the learning process: general didactic aspect]. Moskva: Pedagogika [in Russian].

Bespalko, V.P. (1977). Osnovyi teorii pedagogicheskih system [Foundations of the theory of pedagogical systems]. Voronezh: Izd-vo Voronezhskogo un-ta [in Russian].

Honcharenko, S. (1997). Ukrainskyi pedahohichnyi slovnyk [Ukrainian pedagogical dictionary]. Kyiv: Lybid [in Ukrainian].

Ilina, T.A. (1972). Strukturnosistemnyiy podhod k organizatsii obucheniya [Structural-system approach to the organization of training]. Moskva: Znanie, Vyip. 1. [in Russian].

Lodatko, Ye.O. (2011). Pedahohichni modeli, pedahohichne modeliuvannia i pedahohichni vymiriuvannia: that is that? [Pedagogical models, pedagogical modeling and pedagogical measurements: that is that?]. Vyshcha osvita Ukrainy: Teoretychnyi ta naukovo-metodychnyi chasopys, issue 3, Vol. 1, 339-344 [in Ukrainian].

Miheev, V.I. (2006). Modelirovanie i metodyi teorii izmereniy v pedagogike [Modeling and methods of measurement theory in pedagogy]. Moskva: KomKniga [in Russian].

Nychkalo, N.G. (2004). Razvitie v Ukraine issledovaniy po problemam pedagogiki i psihologii professionalnogo obrazovaniya na rubezhe stoletiy [Development in Ukraine of research on the problems of pedagogy and psychology of vocational education at the turn of the century]. Kyiv: Naukovyi svit [in Ukrainian]. 
Panfilova, A.P. (2006). Igrovoe modelirovanie v deyatelnosti pedagoga [Game modeling in the activities of a teacher]. Moskva: Akademiya [in Russian].

Siaska, I. (2020). The metodology forming of ecological competency of future teachers of natural sciences during vocational training. Scientific Journal of Polonia University, issue 38, No 1, 211-220 [in Poland].

Velykyi tlumachyi slovnyk suchasnoi ukrainskoi movy (2001). [Large explanatory dictionary of the modern Ukrainian language]. V. T. Busel (Ed.). Kyiv; Irpin: VTF «Perun» [in Ukrainian]. Voitovych, O.P. (2018). Teoretychni metodychni zasady formuvannia tekhnolohichnoi kompetentnosti maibutnikh ekolohiv u protsesi fakhovoi pidhotovky [Theoretical methodological bases of formation of technological competency of future ecologists in the process of professional training]. Doctor's thesis. Kyiv [in Ukrainian].

Yakovlev, E.V., Yakovleva, N.O. (2006). Pedagogicheskaya kontseptsiya: metodologicheskie aspektyi postroeniya [Pedagogical concept: methodological aspects of construction]. Moskva: Gumanitarnyiy izdatelskiy tsentr VLADOS [in Russian].

Yakubovski, M.A. (2003). Matematicheskoe modelirovanie professionalnoy deyalnosti uchitelya [Mathematical modeling of the teacher's professional activity]. I.M. Kozlovskoy (Ed.). Lvov: Evrosvit [in Ukrainian]. 